\title{
Köbös bórnitrid lapkás „hosszú” furat esztergakések élettartamának vizs- gálata edzett acél megmunkálásának vonatkozásában
}

\author{
Wallyson Thomas Alves da Silva \\ PhD hallgató, Miskolci Egyetem, Szerszámgépészeti és Mechatronikai Intézet, \\ Szerszámgépek Intézeti Tanszéke \\ 3515 Miskolc, Miskolc-Egyetemváros, e-mail: szmwally@uni-miskolc.hu \\ Fülöp Zsombor \\ PhD hallgató, Miskolci Egyetem, Szerszámgépészeti és Mechatronikai Intézet, \\ Szerszámgépek Intézeti Tanszéke \\ 3515 Miskolc,Miskolc-Egyetemváros, e-mail: fulop.zsombor@uni-miskolc.hu
}

\begin{abstract}
Absztrakt
Cikkünk célja, hogy kiértékeljük a köbös bórnitrid (CBN) lapkás „,hosszan túlnyúló” (továbbiakban ",hosszu'”) furat esztergakések kopási folyamatait fénymikroszkóp segitségével, mellyel a kopás mértéke könnyedén követhetö. A szerszám paramétereit a maximálisan megengedett túlnyúlásig (azaz a dinamikailag stabil forgácsleválasztáshoz tartozó, késszár átméröhöz viszonyitott maximálisan megengedhetö „, hosszig”) vizsgáltuk. Az eredmények rámutatnak az oldalél jelentös kopására a maximálisan megengedett túlnyúlás közelében.
\end{abstract}

Kulcsszavak: szerszámkopás, élettartam, szerszám túlnyúlás, edzett acél

\begin{abstract}
This work aims to monitor the CBN tool wear process using optical microscopy, so that the lifespan of the tool could be verified. The tool overhang was varied until it reached a limit (the deepest hole it could machine). The results show that, when the tool overhang is within its stability range, the flank wear of the tool is accentuated when the tool overhang outreaches its stability limit.
\end{abstract}

Keywords: tool wear, lifespan, tool overhang, hardened steel

\section{Bevezetés, szakirodalom áttekintés}

Ideális esetben a felületi érdességet, illetve annak tulajdonságait a szerszám élprofiljának geometriai kialakítása, méretei, a főorsó fordulatszáma és az előtolás értékei, stb. befolyásolják. Részletesebben vizsgálva a problémát, számos egyéb befolyásoló tényezőt is felfedezhetünk az előbb említett egyszerübb befolyásoló paraméterek mellett. Ilyen például a forgácsleválasztás dinamikai kérdéseinél sokszor emlegetett rugalmas és képlékeny alakváltozási folyamatokkal járó leválasztási folyamat mellett, a főorsó futási hibája és a szerszám rezgése, amelyek viszonylagos elmozdulást (a szerszám és a megmunkált darab között) és felületi minőségromlást eredményeznek. Edzett anyagok esztergálásánál, „hosszú" furat esztergakést alkalmazva (más néven mély furatok belső megmunkálása esetén) ez különösen nehéz feladat. Az előbb említett esetben tehát a szerszám rezgése nagymértékben befolyásolja a felületi érdességet, és ez fordítva is elmondható: a szerszám kopása erősen befolyásolja a szerszám rezgését [1].

Forgácsolási kísérletek során a leválasztandó anyag mennyiségét könnyedén meghatározhatjuk, amely meghatározza a gyártási folyamat termelékenységét, amely alapul szolgál az aktuális szerszám- 
gép teljesítményének meghatározásánál is. Az előtolásból, fogásmélységből, forgácsolási sebességből és a megmunkált anyag átmérőjéből jól számítható az időegység alatt leválasztott anyag térfogata. A megmunkált anyag átmérőjét rendkívül kis átmérő értékeknél szükséges figyelembe venni, amikor a megmunkált átmérő közel van a fogásmélység értékéhez, hogy elkerülhető legyen az anyagleválasztási arány nagy hibája, amely $4 \%$ és $25 \%$ közötti eltérést is mutathat [2].

A megmunkálás egyik egyszerü, kezdeti feltételezése, hogy a váltólapka keménysége nagyobb legyen, mint a megmunkált anyag keménysége. Általában azonban minél nagyobb a lapka keménysége, annál könnyebben válik törékennyé is [3].

Az edzett acélok esztergálása során a CBN lapkák meglehetősen nagy keménysége miatt, a kopási folyamat ellenőrzése alapvető eljárás a lapkák törésének és repedésének elkerülésének érdekében.

A korábbi munkák már rámutattak a köbös bórnitrid (CBN) lapkák felhasználási lehetőségeire az edzett acélok megmunkálásának vonatkozásában, homlok és hosszesztergálás esetén is [4], [5].

\section{Felhasznált anyagok és módszerek}

Az összes furatesztergálási kísérletet CNC esztergán végeztük el, a főorsó maximális 4500-as percenkénti fordulatszáma mellett.

Egy 16 mm-es átmérőjü, ANSI 4140 (ISO A16R SCLCR 09-R) szabvány szerinti nagy keménységü késszárral ellátott, váltólapkás furat esztergakést használtunk fel a kísérletek során. Ami a CBN lapkát illeti, edzett acél felületi simításra - mint forgácsolás befejező műveletére - alkalmas betétet választottunk.

Ezen váltólapka $50 \mathrm{~m} / \mathrm{m} \%$ - ban köbös bórnitridet tartalmaz, továbbá TiCN és A12O3 keramikus fázisból áll az ISO CCGW09T308S01020F 7015 (class ISO H10) szabvány szerint. A választott lapka elönye, hogy nagyobb CBN tartalmú a többi hasonló betéthez viszonyítva, továbbá elegendően nagy keménységgel rendelkezik a megfelelö éltartóssághoz.

A próbadarabok gyártásához használt 4340-es acél széles körben használt alapanyag a gépiparban. Jól edzhető, hegeszthetősége rossz, viszont kedvező megmunkálási tulajdonságokkal és fáradási tulajdonságokkal bír, keménysége 54 és 59 HRc között változik. Két különböző megmunkálási esetet vizsgáltunk. Mindkettőnél több forgácsolási esetet és szerszám túlnyúlást vettünk figyelembe. Elsőként a szerszám élettartamának mérését végeztük el hütőfolyadék nélküli forgácsolás mellett, az ISO 3685 szerinti szerszám tönkremeneteli kritérium figyelembevételével [6]. Ezen kritérium a 0,2 $\mathrm{mm}$-es maximális oldalél kopáshoz (Vbmax) köthető. A második méréssorozatnál pedig a szerszámcsúcs gyorsulást, a sugárirányú és tangenciális összetevőivel együtt határoztuk meg a szerszám élettartama kezdetén és végén.

1. táblázat. Az élettartam vizsgálat során, a megmunkáláskor alkalmazott paraméterek, 70 mm-es szerszámhossz esetén

\begin{tabular}{|c|c|c|}
\hline $\begin{array}{c}\text { Forgácsolási esetek sor- } \\
\text { számai }\end{array}$ & $\begin{array}{c}\text { előtolás } \\
(\mathbf{f})[\mathbf{m m} / \mathbf{f o r d}]\end{array}$ & $\begin{array}{c}\text { forgácsolási sebesség } \\
\left(\mathbf{v}_{\mathbf{c}}\right)[\mathbf{m} / \mathbf{p e r c}]\end{array}$ \\
\hline 1. & 0,08 & 360 \\
\hline 2. & 0,08 & 300 \\
\hline 3. & 0,06 & 300 \\
\hline 4. & 0,06 & 360 \\
\hline
\end{tabular}

A szerszámok élettartamának vizsgálatokhoz egy mátrixot határoztunk meg, amely két faktorból áll kétvariációs szinten, amely négy esetet eredményez. Mindegyik eset egyszeri megismétlésével nyolc teszt elvégzése válik szükségessé. A négy forgácsolási esetet az 1. táblázatban foglaltuk össze. 


\section{Eredmények}

A 2-es táblázat az élettartam vizsgálat során, az alkalmazott megmunkálási paramétereket tartalmazza a szerszám „tönkremeneteléig” vizsgálva. Az eredmények azt mutatják, hogy a különböző üzemeltetési/ megmunkálási esetekben a szerszámok élettartamának végéhez tartozó felületi érdesség értékek nem mutatnak szignifikáns különbséget. A megmunkáló él geometriai méretei azonban jelentős mértékben változnak - főleg a CBN lapka felső síkjában vehető észre jelentős kopás (kráteres kopás) amely jellemzően nagymennyiségü forgácsleválasztást követően jön létre, azonban megjegyezzük, hogy ez esetben az oldalélkopás sokkal erőteljesebb.

Ismeretes, hogy a szerszám élettartama akkor ér véget az ISO 3685-ös szabvány szerint [6], amikor a szerszám oldalélének kopása eléri a 0,2 mm-t. Az forgácsolt anyag eltávolítási sebessége talán lehetővé teszi a szerszámok élettartamának jobb összehasonlítását, mintha csak a forgácsolásban eltöltött időt (összes föidőt) vennénk figyelembe, különösen azokban az esetekben igaz ez, amikor a tényleges forgácsolási sebességet, mint paramétert változtatjuk a kísérlet során. Egyértelmüen megfigyelhető, hogy a nagyobb sebességgel végzett forgácsolási folyamat esetén magasabb megmunkálási hőmérséklettel kell számolnunk, amely a szerszám élettartamát csökkenti. Az elötolás növelésével növekvő élettartamot érhetünk el. Megfigyelhető tehát, hogy az előtolási érték nagyobb hatással bír, mint a forgácsolási sebesség.

2. táblázat. Az élettartam vizsgálat során, a megmunkáláskor alkalmazott paraméterek, 0,1 mm-es fogásmélység esetén

\begin{tabular}{|c|c|c|c|c|c|c|}
\hline \multirow{2}{*}{$\begin{array}{c}\text { Üzemeltetési } \\
\text { esetek sorszámai }\end{array}$} & \multirow{2}{*}{$\begin{array}{c}\mathbf{v} \mathbf{c} \\
{[\mathbf{m} / \mathbf{p e r c}]}\end{array}$} & $\mathbf{f}[\mathbf{m m} / \mathbf{f o r d}]$ & \multicolumn{3}{|c|}{ A szerszám élettartamának végéhez tartozó adatok } \\
\cline { 4 - 7 } & & $\begin{array}{c}\text { Anyageltávolítási } \\
\text { ráta- Q }\left[\mathbf{c m}^{\mathbf{3}} / \mathbf{p e r c}\right]\end{array}$ & $\mathbf{R}_{\mathbf{a}}[\boldsymbol{\mu \mathbf { m } ]}$ & $\mathbf{R}_{\mathbf{z}}[\boldsymbol{\mu m}]$ & $\mathbf{V} \mathbf{B}_{\mathbf{m a x}}[\boldsymbol{\mu m}]$ \\
\hline 1. & 360 & 0,08 & 6,05 & 0,58 & 2,9 & 201,6 \\
\hline 2. & 300 & 0,08 & 7,2 & 0,83 & 3,4 & 234,6 \\
\hline 3. & 300 & 0,06 & 7,56 & 0,5 & 2,72 & 220,8 \\
\hline 4. & 360 & 0,06 & 6,48 & 0,78 & 3,12 & 212,5 \\
\hline
\end{tabular}

Ezen kísérleti tanulmány keretén belül vizsgáltuk azt is, hogy a szerszám kopása milyen hatással van az edzett acél megmunkálásakor létrejövő felületi érdességre. A 2. táblázat mutatja többek között a felületi érdességet, mint $R_{a}$ paramétert - az oldalél kopásának függvényében. Látható, hogy ahogy az oldalélkopás értéke növekszik, úgy romlik a felületi minőség is. Megfigyelhető továbbra az is, hogy amikor még az oldalél kopása körülbelül $0,2 \mathrm{~mm}$ volt, az $R_{a}$ felületi érdesség értéke nem ment, illetve alig ment $0,8 \mu \mathrm{m}$ fölé egyik esetben. Ez egy szemléletes példa arra, hogy az egyenletes oldalélkopással elért $0,2 \mathrm{~mm}$-es kopási érték esetén még nem jön létre jelentős felületi minőség romlás az edzett acél megmunkálására vonatkozóan. Úgy tủnik, hogy az efféle esztergálási műveletet - mint a megmunkálás befejező műveletét - tekinthetjük a furatköszörülés alternatívájaként is. A felületi érdesség romlása azonban drasztikussá válik, túllépve a $0,2 \mathrm{~mm}$-es oldalélkopást.

Az 1. ábra a szerszám oldalélének kopási mértékének alakulását mutatja az idő függvényében - az élettartam teszt során - négyféle üzemeltetési körülmény esetére, $L / D=4,4$ - es túlnyúlási érték mellett. A $V b_{\max }$ maximálisan megengedett oldalélkopás fokozatos alakulását tekintve megállapíthatjuk, hogy nincsen semmiféle müködési hiba, amely a görbék meredekségének hirtelen megváltozásához, így a forgácsoló lapka hirtelen élettartamának végéhez vezetne. 


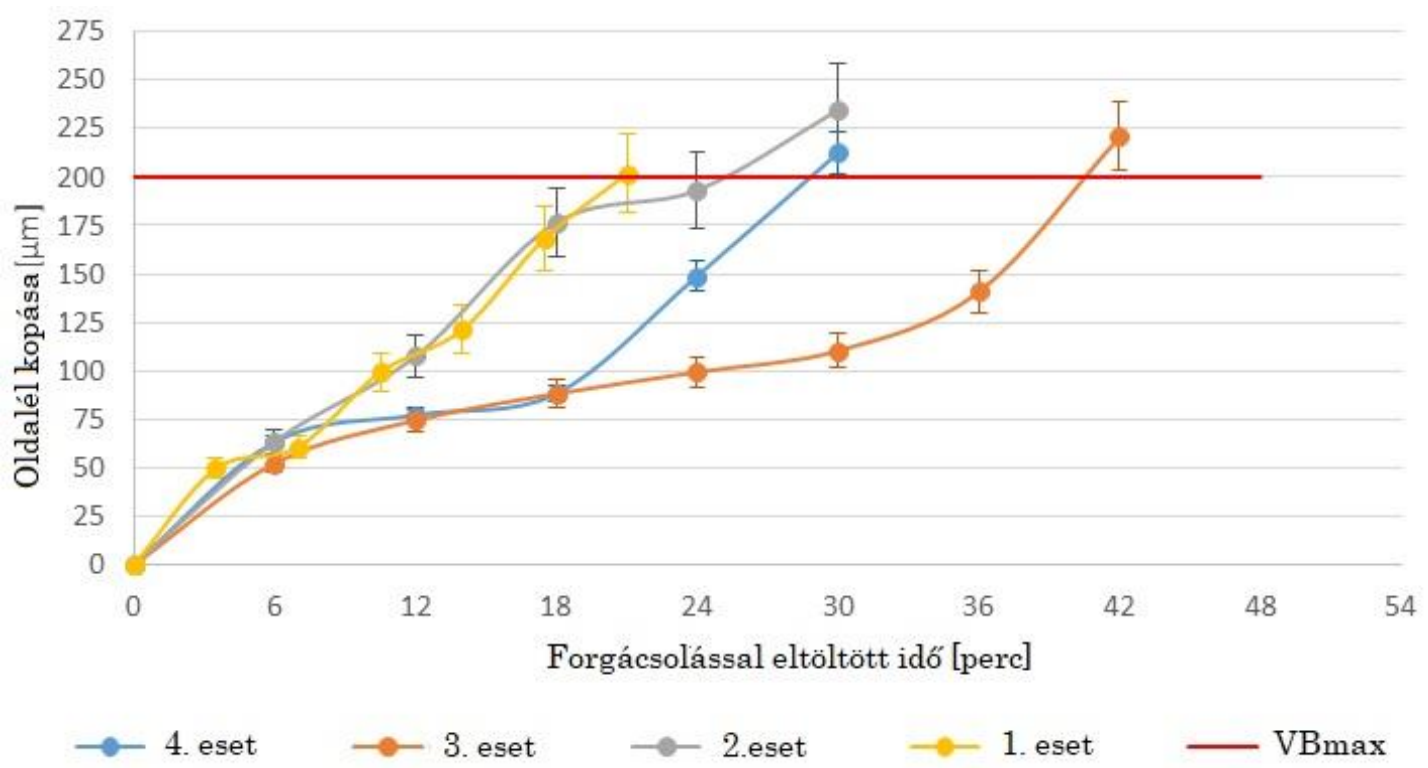

1. ábra. Szerszám oldalélkopása a forgácsolással eltöltött idö függvényében, négyféle üzemeltetési esetben

\section{4. Összefoglalás}

A kopási folyamatok vizsgálata során megállapítottuk, hogy a „hosszú” furat esztergakésekkel végzett folyamatos megmunkálás esetén a szerszámlapka oldalélkopását főképpen a köbös bórnitrid leváló részecskéi okozzák, edzett acél megmunkálásának vonatkozásában. Megfigyeltük továbbá azt is, hogy abban az esetben is, amikor a köbös bórnitrid lapka oldalél kopása eléri a $0,2 \mathrm{~mm}$-t, az $R_{a}$ felületi érdesség értéke kevesebb, mint $0,8 \mu \mathrm{m}$, a dinamikailag stabil forgácsleválasztási folyamat miatt.

\section{Köszönetnyilvánítás}

A cikkben ismertetett kutató munka az EFOP-3.6.1-16-2016-00011 jelü „Fiatalodó és Megújuló Egyetem - Innovatív Tudásváros - a Miskolci Egyetem intelligens szakosodást szolgáló intézményi fejlesztése" projekt részeként - a Széchenyi 2020 keretében - az Európai Unió támogatásával, az Európai Szociális Alap társfinanszírozásával valósul meg.

\section{Irodalom}

[1] Bhaskaran, J.: Process monitoring of hard turning using acoustic emission technique, (2011).

[2] Isakov, E.: Cutting data for turning of steel, p.179, Table 4.2, Industrial Press, Inc., 2009, New York, NY 10018.

[3] Suyama, D. I.: Uma contribuição ao estudo do torneamento interno em aços endurecidos, Doctoral Thesis, UNICAMP, Campinas, São Paulo, Brazil, 2014.

[4] Adilson, J. de Oliveira, Diniz, A. E., Ursolino, D. J.: Hard turning in continuous and interrupted cut with PCBN and whisker-reinforced cutting tools, Journal of Materials Processing Technology 209.12 (2009): 5262-5270. https://doi.org/10.1016/j.jmatprotec.2009.03.012 
Wallison, T. A. de S., Fülöp, Zs.

Esztergakések élettartam vizsgálata

[5] Vitor, A. A. de Godoy, Diniz, A. E.: Turning of interrupted and continuous hardened steel surfaces using ceramic and CBN cutting tools, Journal of Materials processing technology 211.6 (2011): 1014-1025. https://doi.org/10.1016/j.jmatprotec.2011.01.002

[6] ISO 3685 tool-life testing with single-point turning tools 